\title{
The influence of complex additives based on calcined clays and carbonate fillers on hydration products composition of blended cement stone
}

\author{
Elizaveta Ermilova ${ }^{*}$ [0000-0001-5008-1265], and Zagira Kamalova2 [0000-0002-7232-1714] \\ ${ }^{1}$ LLC «Engineering Center of High-Rise Special Technology, 420088, Russia \\ ${ }^{2}$ Kazan State University of Architecture and Engineering, 420043, Zelenaya st., Kazan, Russia
}

\begin{abstract}
One of the most effective and recognizable way to solve energy and resource consumption problems in cement industry is the development of blended Portland cement with different combinations of mineral additives. The development of complex additives based on combination of calcined clays and limestone is one of the promising directions. The aim of this work was to study the influence of complex additives based on calcined kaolinitic clay with kaolinite content of $80 \%$ and limestone with calcite content of $99 \%$ on the blended cement stone hydration products at the age of 28 days. Using X-ray diffraction and differential scanning calorimetry the composition of blended cement stone hydration products was studied. It is established that the introduction of $20 \%$ of the complex additive based on calcined clay and limestone leads to a significant decrease of the portlandite content, increase in the number of new growths in form of low-calcium hydrosilicates and calcium hidrocarboalumosilicates, stabilization of ettringiteand calcium hydrocarbosilicates in amorphous phase, that significantly increases the compressive strength. This effect was amplified due to the additional alumina provided by calcined clay reaction.
\end{abstract}

Keywords: blended Portland cement, mineral additives, calcined clay, limestone.

\section{Introduction}

Production of Portland cement (OPC) is characterized by high energy and resource consumption and significant amounts of polluting emissions. One of the most effective and recognizable way to solve these problems in cement industry is the development of lowclinker blended Portland cement with mineral additives. Despite the GOST 31108-2003 introduced in Russia in 2003, according to which 11 of 12 different types of Portland cement are Portland cements with a mineral additive content of up to $65 \%$, today the average content of mineral additives in Portland cements in Russia is only $13 \%$ [1] , while the world indicator is at the level of $20 \%$ [2-4]. The reason for this is the lack of available

\footnotetext{
* Corresponding author: lizabeta 91@list.ru
} 
mineral supplements with large stocks to meet the growing demand for them.

The product of calcined kaolin clays - metakaolin - is considered as one of the most effective mineral additives. However its reserves are limited not only geographically, but also quantitatively [3]. Thus, the share of the Russian Federation, which occupies about 1/9 of the land area of the entire globe, accounts for only $3 \%$ of the world's kaolin reserves. Therefore, recently, scientists have been working on the search for effective pozzolanic materials from thermally activated polymineral clays with a low content of kaolinite and its complete absence [4-6]. At the same time, it was found that the combined use of polymineral clays with carbonate additives leads to the emergence of a synergistic effect, expressed in an increase in technical and operational parameters of obtained materials [715]. Complex additives which differ by presence of a synergetic effect in the cointroduction of multiple mineral additives are of great importance while the creation of blended cements [1-7]. One of the promising directions is the creation of complex additives based on the combination of calcined clays, including kaolinite with limestone. The effectiveness of the joint introduction is achieved when the content of component is 2:1 (clay: limestone) [16]. The role of limestone in the formation of monocarbonate calcium is noted [17].

In the article [9] the results of studies of complex additives based on polymineral kaolinitic clay and carbonate rocks based on blended cement stone properties, according to the maximum efficiency achieved for carbonate rocks with $99 \%$ calcite content were published.

In this work the complex additive based on thermoactivated clay and limestone effect on the hydration products of blended cement stone at the age of 28 days was study.

\section{Materials and methods}

\subsection{Materials and characteristic}

All experiments were carried out using the OPC CEM I 42,5 N according EN 197-1 (C $\mathrm{C}_{3} \mathrm{~S}-$ 68,$\left.0 ; \mathrm{C}_{2} \mathrm{~S}-10,0 ; \mathrm{C}_{3} \mathrm{~A}-3.7 ; \mathrm{C}_{4} \mathrm{AF}-15\right)$. As polymineral clays were selected the kaolinitic clay of Novoorsk field (Orenburg region, Russia) (chemical composition, mass \%: CaO-0,20; $\mathrm{SiO}_{2}-69,18 ; \mathrm{Al}_{2} \mathrm{O}_{3}-19,55 ; \mathrm{Fe}_{2} \mathrm{O}_{3}-1,32 ; \mathrm{MgO}-0,42 ; \mathrm{SO}_{3}-<0,05 ; \mathrm{Na}_{2} \mathrm{O}-<0,3 ; \mathrm{K}_{2} \mathrm{O}-0,92 ;$ $\mathrm{TiO}_{2}-1,36 ; \mathrm{MnO}-0,01 ; \mathrm{P}_{2} \mathrm{O}_{5}-<0,3$; LOI - 6,63). The specific surface is $500 \mathrm{~m}^{2} / \mathrm{kg}$. Limestone from Dobryatinsk deposits of Vladimir region, Russia was adopted as a carbonate rock.

The mineral compositions of materials are presented in Table 1. The differential thermal curve of clay is shown in Fig. 1.

Table 1. Mineral compositions of clays.

\begin{tabular}{|c|c|c|}
\hline Mineral composition (\%) & Kaolinitic clay & Limestone \\
\hline Kaolinite & 82.3 & - \\
\hline Quartz & 17.7 & 1 \\
\hline Calcite & - & 99 \\
\hline
\end{tabular}




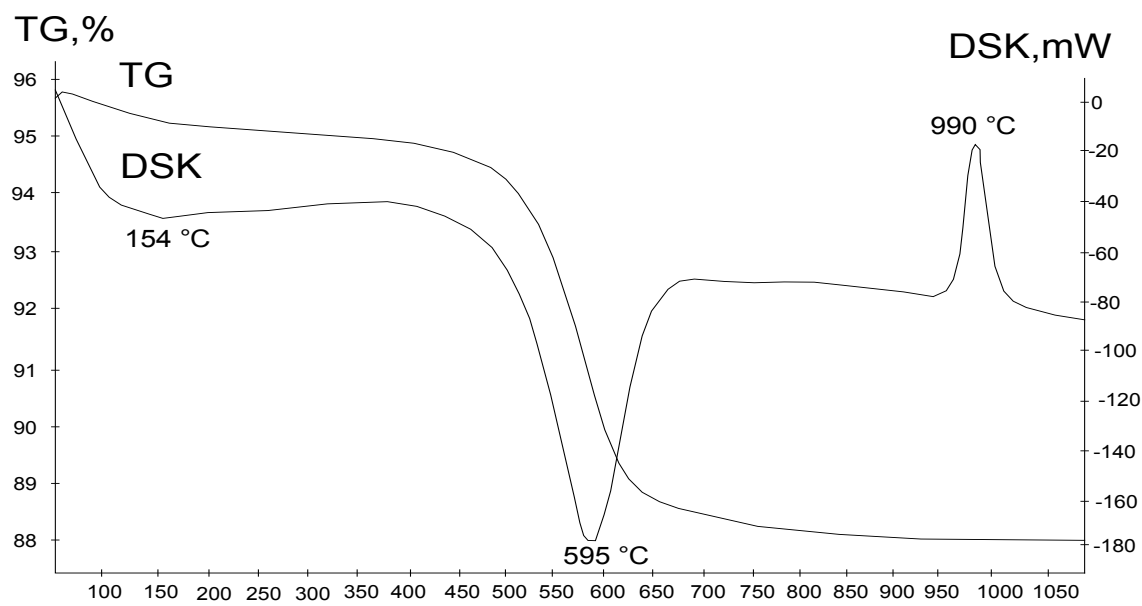

Fig. 1. Simultaneous TG-DTA data of kaolinitic clay.

\subsection{Methodology}

The calcination of clay was conducted in the laboratory chamber furnace SNOL 7.2/1300 with the chamber of vacuum fiber. The rate of kaolinitic clay heating was adopted equal to $10^{\circ} \mathrm{C} / \mathrm{min}$ according to studies [18].

Experiments were carried out on samples-cubes of cement stone with the edge of $2 \mathrm{~cm}$. Physical-mechanical properties of cement stone of normal density was evaluated from variation of compressive strength, water absorption and average density.

Calcined mixtures were introduced into the OPC in amount of $20 \%$ of its mass according to the GOST 31108-2003 and the EN 197-1:2000.

The thermal analysis of clay and limestone mixtures, and blended cement stone was carried out using a combined method of thermogravimetry (TG) and differential scanning calorimetry (DSC) using thermoanalyzer NETZSCH STA 449C under continuous heating (40 to $1000{ }^{\circ} \mathrm{C}$ ) of samples with a mass of about $35-40 \mathrm{mg}$ at a rate of $10^{\circ} \mathrm{C} / \mathrm{min}$ in a flow $(50 \mathrm{ml} / \mathrm{min})$ of air in alund crucibles. Temperatures of thermal effects are determined with an accuracy of $\pm 1-3^{\circ} \mathrm{C}$, warmth $- \pm 5 \%$, weight of $\pm 0.01 \mathrm{mg}$.

The determination of mineralogical composition thermoactivated mixtures, changes, and identification of hydration products was carried out using X-ray phase analysis on the automatic X-ray diffraction D2 Phaser (Bruker company). CuK $\alpha$ radiation, monochromatization $(\lambda(\mathrm{Cu}-\mathrm{Ka})=1.54184 \AA)$ curved germanium monochromator of Johansson, the mode of operation of X-ray tube $40 \mathrm{kV}, 40 \mathrm{~mA}$ was used. The experiments were performed at room temperature in the geometry of Bragg-Brentano flat sample. Analysis and plotting of diffraction patterns was carried out using the program Bruker Diffrac Eva.

\section{Results and discussion}

The complex additive was introduced in an amount of $20 \%$ by Portland cement weight. Based on the data obtained [9], the carbonate rock content in the complex additive was 30 $\%$ by additive weight.

The specific surface of mixtures was $500 \mathrm{~m}^{2} / \mathrm{kg}$. 


\subsection{Hydration products composition of blended cements with the complex additive}

The research of hydration products composition was conducted on cement stone samples while 28 days with the following compositions:

1. The control sample of OPC;

2. The blended cement with $20 \%$ of complex additive based on calcined kaolinitic clay and limestone.

In the Fig. 2 XRD pattern of control sample OPC cement stone is submitted.

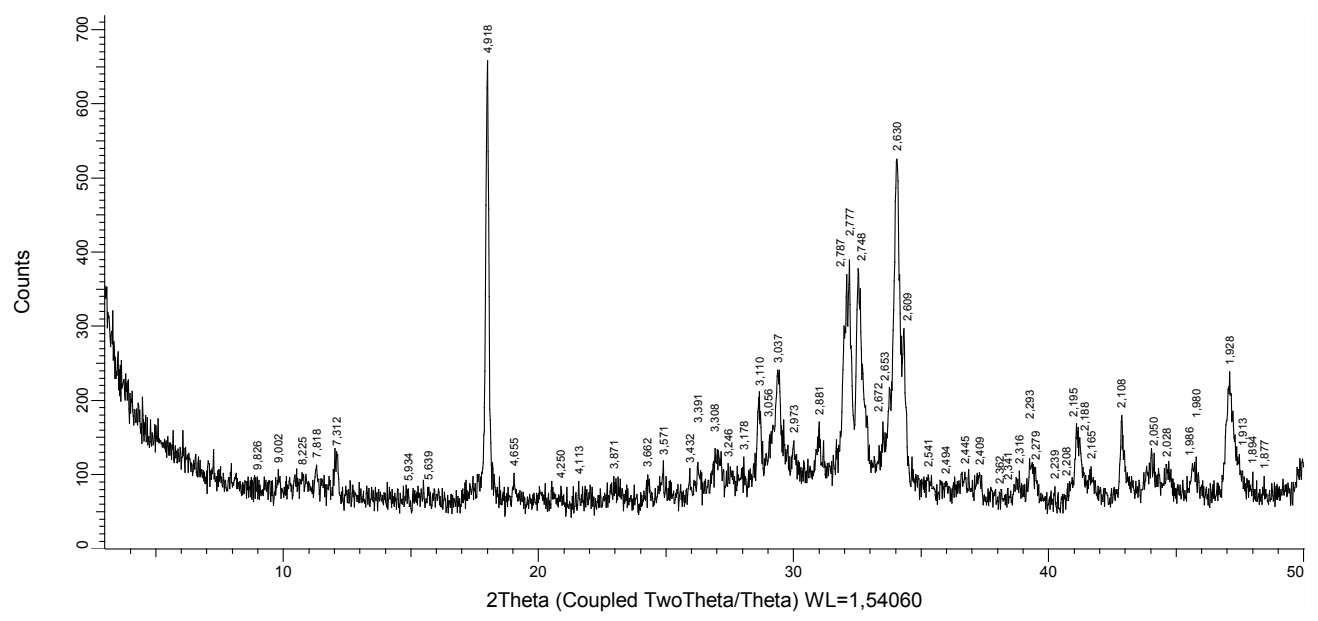

Fig. 2. XRD pattern of control sample from the OPC cement stone.

It's structure is characterized by larger peaks of unreacted clinker minerals - an alite $(\mathrm{d}=$ $(2.748 ; 2.609 ; 2.316 ; 2.188) \cdot \AA)$ and a belite $(\mathrm{d}=(4.655 ; 2.787 ; 2.777 ; 2.293 ; 2.195 ; 2.050$; $2.028 ; 1.980) \cdot \AA)$. The diffraction peaks with interplanar distances $d=(7.312 ; 4.260 ; 3.178$; $2.672) \cdot \AA$ correspond to calcium hydroaluminosilicates. The presence of small content of calcite $(\mathrm{d}=(3.037 ; 2.494 ; 1.913 ; 1.877) \cdot \AA)$ and the formed ettringite $(\mathrm{d}=(9.826 ; 5.934) \cdot \AA)$ is observed. The presence of calcium hydromonosulfoaluminate is characterized by the diffraction peaks with interplanar distances $\mathrm{d}=(9.002 ; 3.432 ; 2.973) \cdot \AA$.

Diffraction peaks with interplanar distances $\mathrm{d}=(8.225 ; 3.871 ; 2.881 ; 2.208) \cdot \AA$ are characterized hydrocalcium silicates C-S-H (I).

In the Fig. 2 the portlandite quantity is considerable and it corresponds diffraction peaks with interplanar distances $\mathrm{d}=(4.918 ; 3.110 ; 2.630 ; 1.928) \cdot \AA$.

The Fig. 3 shows the X-ray diffraction pattern of the blended cement stone sample with a $20 \%$ complex mineral additive based on calcined kaolinitic clay and limestone. Most of the diffraction maxima with the highest intensity refer to limestone calcium carbonate with interplanar spacings $d=(3.859 ; 3.041 ; 2.494 ; 2.283 ; 2.096 ; 1.877) \AA$. 


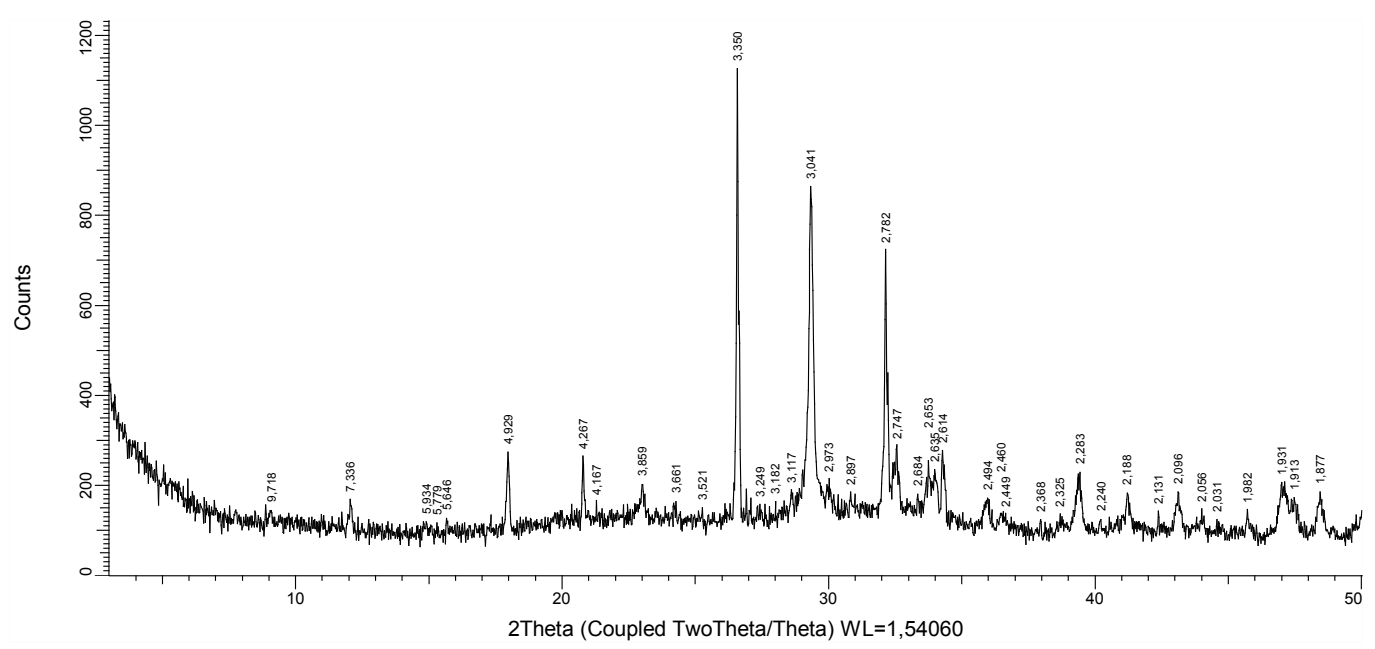

Fig. 3. XRD pattern of blended cement stone sample with $20 \%$ of complex additive based on calcined kaolinitic clay and limestone.

The diffractogram indicates a large presence of carboaluminate phases. There is a complete transition of calcium hydromonosulfoaluminate $\left(3 \mathrm{CaO} \cdot \mathrm{Al}_{2} \mathrm{O}_{3} \cdot \mathrm{CaSO}_{4} \cdot(11-12) \mathrm{H}_{2} \mathrm{O}\right)$ in Portland cement on the $\mathrm{CaCO}_{3}$ particles surface into calcium hydromonocarboaluminates $\left(3 \mathrm{CaO} \cdot \mathrm{Al}_{2} \mathrm{O}_{3} \cdot \mathrm{CaCO}_{3} \cdot(11-12) \mathrm{H}_{2} \mathrm{O}\right)$ [12] with interplanar distances $\mathrm{d}=(4.267 ; 4.167$; $3.661 ; 3.521 ; 3.117 ; 2.653) \AA[10]$. It should be noted that the limestone amount and its activity are sufficient for the entire hydrosemicarboaluminate $\left(3 \mathrm{CaO} \cdot \mathrm{Al}_{2} \mathrm{O}_{3} \cdot 0.5 \mathrm{CaCO}_{3}\right.$. (11-12) $\mathrm{H}_{2} \mathrm{O}$ ) to turn into calcium hydrogen monocarboaluminate [11].

In the composition of the blended cement stone with the complex additive, there is a small content of ettringite $(\mathrm{d}=(9.718 ; 5.646) \cdot \AA)$, approximately the same as in the control composition. Portlandite content $(\mathrm{d}=(4.929 ; 2.614 ; 1.931) \AA)$ is almost 5 times lower compared to the control sample. Diffraction maxima with interplanar distances $d=(7.336$; 3.249) A correspond to calcium hydroaluminosilicates, the content of which is less than in the control sample. Almost the same amount of clinker minerals as in the control sample remains unhydrated, as evidenced by diffraction maxima with interplanar distances $\mathrm{d}=$ $(2.782 ; 2.449 ; 2.188 ; 1.982) \cdot \AA$, characteristic of belite and $\mathrm{d}=(2.747 ; 2.635) \cdot \AA$ characteristic of alite. Most of neoplasms are in low-basic form, weakly crystallized hydrosilicates $\mathrm{C}-\mathrm{S}-\mathrm{H}(\mathrm{I})(\mathrm{d}=(2.897 ; 2.188) \cdot \AA)$ and amorphous hydroaluminosilicates of the $\mathrm{C}-\mathrm{A}-\mathrm{S}-\mathrm{H}$ type and hydrocarbosilicates [13], which is confirmed by an increase in amorphous phase up to $43 \%$, which is $10 \%$ higher compared to the control sample.

In the Fig. 4 the simultaneous TG-DTA data of control OPC cement stone sample is presented. The observed endothermic effect with the maximum at $70{ }^{\circ} \mathrm{C}$ can be bound with loss of free water from a cement stone [15]. Also there is one more effect $\left(100-125^{\circ} \mathrm{C}\right)$ which is not absolutely accurately expressed on DSC and is connected with loss of adsorption water [15].

The small endothermic peak at the temperature range $125-150{ }^{\circ} \mathrm{C}$ is caused by the ettringite dehydration $[14,15]$. The endothermic effect with the maximum at $461{ }^{\circ} \mathrm{C}$ and loss of weight $1.86 \%$ characterizes the calcium hydroxide decomposition [15]. The loss of weight in temperature range of $480-630{ }^{\circ} \mathrm{C}$ is $2.87 \%$. The endothermic effect with a maximum at $680{ }^{\circ} \mathrm{C}$ is followed by loss of weight in $4.82 \%$ and characterizes the lime carbonate decomposition formed during the hardening [15]. 


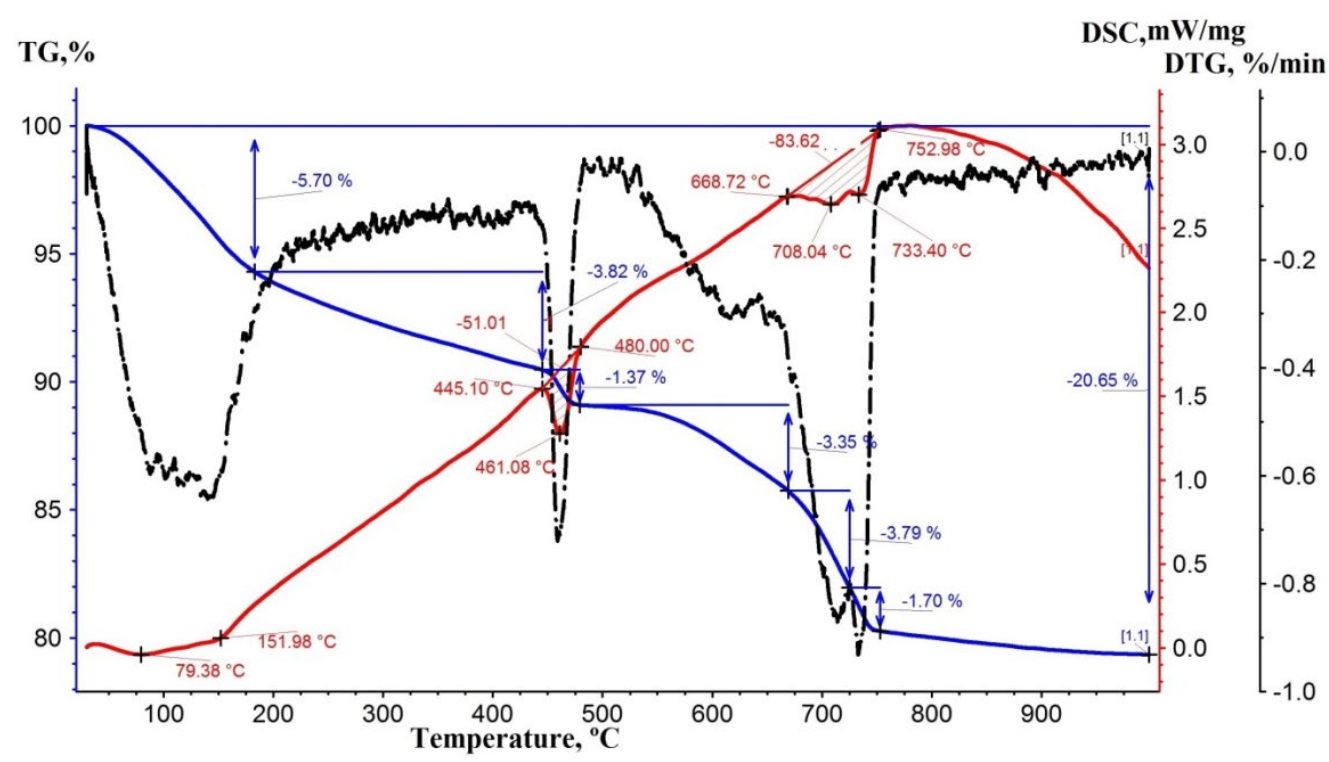

Fig. 4. Simultaneous TG-DTA-DSC data of control OPC cement stone sample.

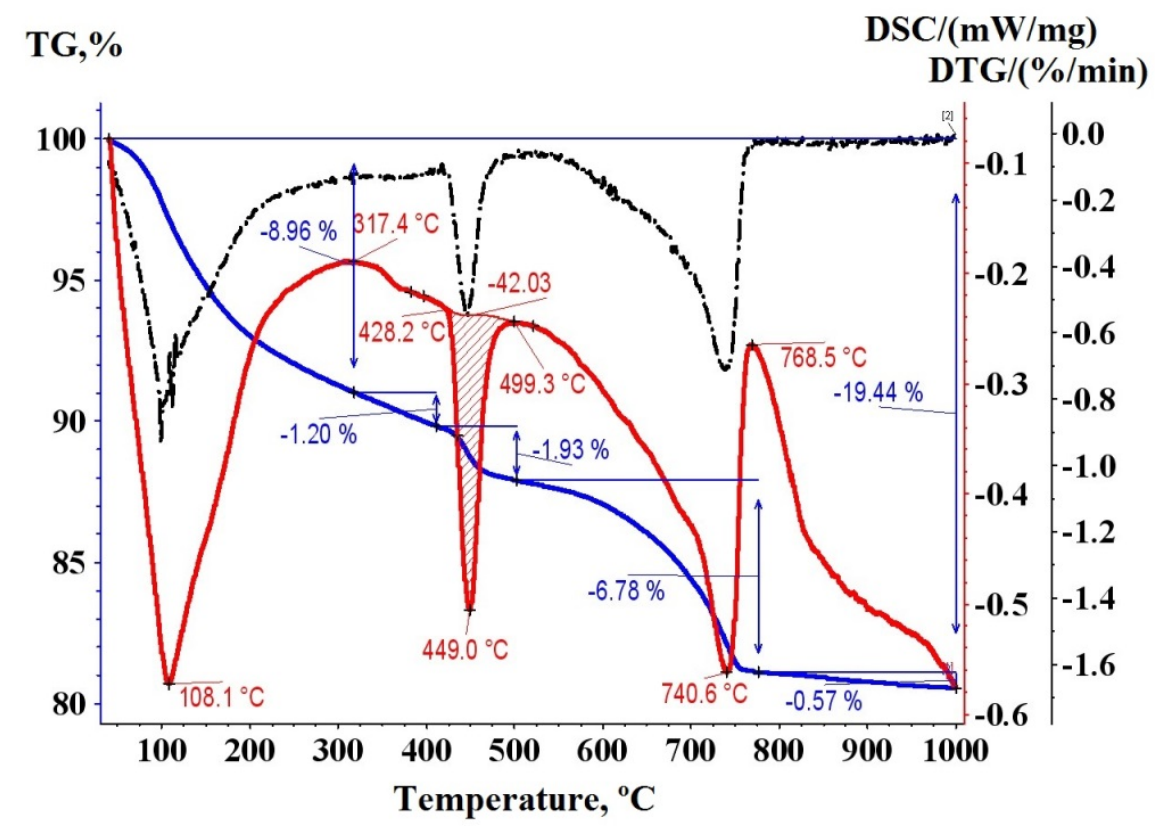

Fig. 5. Simultaneous TG-DTA-DSC data of blended cement stone sample with $20 \%$ of complex additive based on calcined kaolinitic clay and limestone.

The thermogram of a blended cement stone sample with a $20 \%$ complex additive is shown in Fig. 5. The endothermic effect is observed with the temperature maximum at $108.1{ }^{\circ} \mathrm{C}$, which combines several endothermic effects located in close proximity to each other. It is associated with the loss of free and adsorbed water by low-basic hydrosilicates of the $\mathrm{C}-\mathrm{S}$ - H (I) type [14], as well as aluminum-substituted hydrosilicates [19]. In the temperature 
range $150-175^{\circ} \mathrm{C}$, a small endothermic effect is associated with the ettringite dehydration. Weight loss at up to $317.4{ }^{\circ} \mathrm{C}$ is $8.96 \%$.

The next endothermic effect is observed at the temperature maximum at $449.0^{\circ} \mathrm{C}$ and is characterized by the portlandite decomposition [15]. The magnitude of the heat effect of portlandite decomposition is $42.03 \mathrm{~J} / \mathrm{g}$, which is $13 \mathrm{~J} / \mathrm{g}$ less than the control sample. This fact indicates the ongoing pozzolanic reaction.

The endothermic effect with the temperature maximum at $740.6{ }^{\circ} \mathrm{C}$ is characterized by the decomposition of limestone relict calcium carbonate. A small protrusion in the temperature range of $680-700{ }^{\circ} \mathrm{C}$ characterizes the decomposition of the formed calcium carbonate in the process of hydration and hardening of the cement stone with the complex additive. The weight loss is $6.78 \%$. In general, when the sample is heated to $1000^{\circ} \mathrm{C}$, the total weight loss is $19.44 \%$.

\section{Conclusions}

Using the methods of X-ray phase analysis and differential scanning calorimetry, it was shown that the introduction of complex additives based on polymineral calcined clay with kaolinite content of $82 \%$ and carbonate rock with calcite content of $99 \%$ leads to the calcium hydrocarboaluminates formation, which stabilizes the ettringite formation and give strength to the cement stone. It was also found that the introduction of complex additives leads to an increase of the amount of low-basic calcium hydrosilicates of the $\mathrm{C}-\mathrm{S}-\mathrm{H}$ (I) type and calcium hydrocarbosilicates in the amorphous state.

\section{References}

1. K. Fleiger, V. Hoenig, A. Wolter, Oxyfuel: prospects and limits, International Cement Review, 8, 71-74 (2014)

2. L. I. Scoble, Cement industry in the former Soviet Union today: an inside look. Tsement i ego primenenie, 1, 28-29 (2016)

3. Proc. $15^{\text {th }}$ International Congress on the Chemistry of cement, 16-20 September 2019, Prague Czech Republic, I, (2019)

4. B. Lothenbach, K. Scrivener, R. D. Hooton, Supplementary cementitious materials. Cem. Concr. Res., 41 (12), 1244-1256 (2011). DOI:10.1016/j.cemconres.2010.12.001.

5. S. E. Schulze, Y. Rickert, The properties of cements with calcined clays as a main component, Tsement i ego primenenie, 1, 152-156 (2016)

6. E. Yu. Ermilova, Z. A. Kamalova, R. Z. Rakhimov, O. V. Stoyanov, S. A. Savinkov, Thermally-activated clay as an alternative replacement of metakaolin in blended Portland cement, Vestnik Kazanskogo tekhnologicheskogo universiteta, 18, 4, 175-179 (2015)

7. R. Mukhametrakhimov, A. Galautdinov, L. Lukmanova, Influence of active mineral additives on the basic prop-erties of the gypsum cement-pozzolan binder for the manufacture of building products, MATEC Web of Conferences, 1-9 (2017) DOI:10.1051/matecconf/201710603012

8. V. Kunter, Ch. Dai, Y. Skibsted, Thermodynamic modeling in the system of Portland cement-metakaolin-limestone: potential factors affecting mechanical properties, Tsement i ego primenenie, 3, 119-124 (2015)

9. E. Yu. Ermilova, Z. A. Kamalova, R. Z. Rakhimov, R. I. Gulyaeva, The research of the influence of complex additives based on calcined clays and carbonate fillers on the composition of hydration products of blended cement stone, Izvestiya KGASU 1, 198205 (2017) 
10. R. Mukhametrakhimov, A. Galautdinov, P. Gorbunova, T. Gorbunova, Water-resistant fiber-reinforced gypsum cement-pozzolanic composites, International Scientific Conference "Construction and Architecture: Theory and Practice for the Innovation Development", E3S Web of Conferences, 2019. (2019). DOI: 10.1051/e3sconf/201913801011.

11. M. Steenbergen, D. Herford, S. L. Poulsen, Y. Skibsted, Y. C. Damtoft, Blended cement based on Portland cement, limestone and calcined clay, Tsement i ego primenenie, $\mathbf{5}$, 44-49 (2014)

12. V. C. Ramachandran, Z. Chun Mei, Influence of $\mathrm{CaCO}_{3}$ on hydration and microstructural charakteristies of tricalcium silicate, Cemento, 3, 129-152 (1986)

13. V. K. Kozlova, A. M. Manoha, A. A. Likhosherstov, E. V. Manuilov, E. Y. Malova, Features composition of hydration products of Portland cement with a carbonatecomposite additives, Cement i ego primenenie, 4, 103-105 (2014)

14. I. A. Makarova, N. Lokhova, Physico-chemical methods for research of construction materials: training manual (Bratsk: Publisher Bratsk state University, 2011)

15. V. S. Ramachandran, Application of differential thermal analysis in chemistry of cement (Moscow: Stroyizdat, 1977)

16. M. Antoni, J. Rossen, F. Martirena, K. Scrivener, Cement substitution by a combination of metakaolin and limestone, Cem. and Conc. Res., 42, 1579-1589 (2012) DOI:10.1016/j.cemconres.2012.09.006.

17. E. Yu. Ermilova, Z. A. Kamalova, R. Z. Rakhimov, O. V. Stoyanov, Blended Portland cement with complex mineral additive based on metakaolin and limestone, Vestnik of Kazan national research technological university, 18 (8), 98-101 (2015)

18. V. A. Voznesensky, T. V. Lyashenko, B. L. Ogarkov, Numerical solution methods of construction and technological problems on a computer (Kiev: Higher school, 1987)

19. P. Rovnanikova, P. Bayer, P. Rovnanik, Corrosion resistivity of concrete with brick powder, in Proc. of the International Conf. Non-traditional cement \& concrete, 19-22 June 2017, Brno, Czech Republic, 113-121 (2017) 